Utah State University

DigitalCommons@USU

$9-12-2018$

\title{
Spatial and Temporal Changes in Ecosystem Carbon Pools Following Juniper Encroachment and Removal
}

\author{
Heather L. Throop \\ Arizona State University \\ Kate Lajtha \\ Oregon State University
}

Follow this and additional works at: https://digitalcommons.usu.edu/sagestep_articles

Part of the Plant Sciences Commons

\section{Recommended Citation}

Throop, H.L., Lajtha, K. Spatial and temporal changes in ecosystem carbon pools following juniper encroachment and removal. Biogeochemistry 140, 373-388 (2018). https://doi.org/10.1007/

s10533-018-0498-y

This Article is brought to you for free and open access by the Publications at DigitalCommons@USU. It has been accepted for inclusion in Articles by an authorized administrator of DigitalCommons@USU. For more information, please contact digitalcommons@usu.edu.

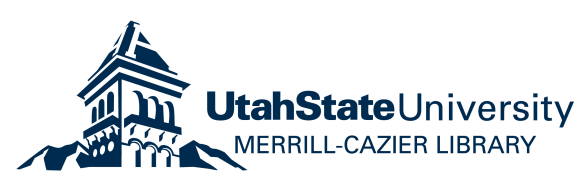




\title{
Spatial and temporal changes in ecosystem carbon pools following juniper encroachment and removal
}

\author{
Heather L. Throop (1) - Kate Lajtha
}

Received: 29 April 2018/Accepted: 4 September 2018/Published online: 12 September 2018

(C) Springer Nature Switzerland AG 2018

\begin{abstract}
Proliferation of woody plants is a predominant global land cover change of the past century, particularly in dryland ecosystems. Woody encroachment and its potential impacts (e.g., livestock forage, wildlife habitat, hydrological cycling) have led to widespread brush management. Although woody plants may have substantial impacts on soils, uncertainty remains regarding woody encroachment and brush management influences on carbon (C) pools. Surface C pools (shallow soils and litter) may be particularly dynamic in response to encroachment and brush management. However, we have limited understanding of spatiotemporal patterns of surface C responses or how surface pools respond relative to
\end{abstract}

Responsible Editor: R. Kelman Wieder.

Electronic supplementary material The online version of this article (https://doi.org/10.1007/s10533-018-0498-y) contains supplementary material, which is available to authorized users.

H. L. Throop ( $\square)$

School of Earth and Space Exploration, Arizona State University, Tempe, AZ 85287, USA

e-mail: heather.throop@asu.edu

\section{H. L. Throop}

School of Life Sciences, Arizona State University, Tempe, AZ 85287, USA

\section{K. Lajtha}

Department of Crop and Soil Science, Oregon State University, Corvallis, OR 97331, USA aboveground $\mathrm{C}$, litter, roots, and deep soil organic $\mathrm{C}$. Spatial variability and lack of basic ecological data in woody-encroached dryland ecosystems present challenges to filling this data gap. We assessed the impact of western juniper (Juniperus occidentalis) encroachment and removal on $\mathrm{C}$ pools in a semi-arid sagebrush ecosystem. We used spatially-intensive sampling to create sub-canopy estimates of surface soil C (0-10 cm depth) and litter $\mathrm{C}$ pools that consider variation in tree size/age and sub-canopy location for live juniper and around stumps that were cut 7 years prior to sampling. We coupled the present size distribution of junipers with extensive existing allometric information about juniper in this region to estimate how landscape-level C pools would change through time under future management and land cover scenarios. Juniper encroachment and removal leads to substantial changes in $\mathrm{C}$ pools. Best-fit models for surface soil and litter $\mathrm{C}$ included positive responses to shrub basal diameter and negative responses to increasing relative distance from the bole to dripline. Juniper removal led to a net loss of surface $\mathrm{C}$ as a function of large decreases in litter $\mathrm{C}$ and small increases in surface soil C. At the landscape scale, deep soil $\mathrm{C}$ was the largest $\mathrm{C}$ pool $\left(77 \mathrm{Mg} \mathrm{C} \mathrm{ha}^{-1}\right)$, with an apparent lack of sensitivity to management. Overall, encroachment led to substantial increases in C storage over time as juniper size increased (excluding deep soil C, ecosystem $\mathrm{C}$ pools increased from 13.5 to 30.2 $\mathrm{Mg} \mathrm{C} \mathrm{ha}^{-1}$ with transition from sagebrush- 
dominated to present encroachment levels). The largest pool of accumulation was juniper aboveground $\mathrm{C}$, with important other pools including juniper roots, litter, and surface soil C. Woody encroachment and subsequent brush management can have substantive impacts on ecosystem $\mathrm{C}$ pools, although our data suggest the spatiotemporal patterns of surface $\mathrm{C}$ pools need to be properly accounted for to capture $\mathrm{C}$ pool responses. Our approach of coupling spatially-intensive surface $\mathrm{C}$ information with shrub distribution and allometric data is an effective method for characterizing ecosystem $\mathrm{C}$ pools, offering an opportunity for filling in knowledge gaps regarding woody encroachment and brush management impacts on local-toregional ecosystem $\mathrm{C}$ pools.

Keywords Shrub - Litter - Brush management . Juniperus $\cdot$ Sagebrush $\cdot$ Artemisia

\section{Introduction}

Encroachment of woody plants into historical shrublands and grasslands is occurring across the globe (Archer 1994; Naito and Cairns 2011; Van Auken 2000), with important ecological, economic, and hydrological consequences. Although the causes of this encroachment are debated and likely differ among sites, the primary causes appear largely anthropogenic. Possible explanations include increased livestock grazing, suppression of fire, climate warming and/or drying, increased $\mathrm{N}$ deposition, and declines in populations of browsing animals (Archer et al. 1995, 2017; Naito and Cairns 2011; Van Auken 2000). Woody encroachment may alter forage availability for livestock and habitat for native species such as the sage grouse (Baruch-Mordo et al. 2013), and considerable research is underway to find effective management methods to limit or reverse this encroachment (McIver et al. 2014). Less well understood is the extent to which woody encroachment, and subsequent brush management, influences ecosystem properties such as above and belowground diversity, fire susceptibility, and carbon (C) storage.

The implications of land cover change from woody encroachment for regional and global biogeochemical cycles are not well understood, but evidence suggests that woody encroachment has significant consequences for continental C dynamics (Houghton 2003; King et al. 2007; Pacala et al. 2001). Woody encroachment may affect $\mathrm{C}$ pools and fluxes through increased stocks of long-lived woody materials aboveground, increased woody root mass, increased litter pools, and alteration of herbaceous biomass. While woody encroachment has consistently been shown to increase total aboveground biomass (Barger et al. 2011; Knapp et al. 2008), generalizations regarding changes in soil organic $\mathrm{C}$ (SOC) pools have been elusive (Barger et al. 2011). Increased live biomass from woody encroachment likely represents a temporary and transient pool of ecosystem $\mathrm{C}$, as stable SOC pools may have turnover times several orders of magnitude greater than that of aboveground vegetation (Sollins et al. 2009). Similarly, detritus on the soil surface can be expected to change with woody plant biomass, although this represents a relatively ephemeral and poorly characterized pool of ecosystem C. Long-term changes in SOC pools may be particularly hard to estimate as woody plant encroachment alters the density and distribution of herbaceous plants, patterns of soil erosion, and litter decomposition (Eldridge et al. 2011; Okin et al. 2001; Throop and Archer 2007). While scientific study of woody encroachment and brush management has increased in recent years, particularly with respect to biogeochemical pools and processes (Archer and Predick 2014; Archer et al. 2017), few studies have assessed how these land cover and management changes affect comprehensive ecosystem-level carbon pools (e.g., aboveground, root, litter, surface soil, and deep soil C) and how these patterns change through space and time. This data gap is in part due to high spatial heterogeneity $\mathrm{C}$ pools and lack of basic ecological information needed to construct ecosystem $\mathrm{C}$ pools in many woody-encroached dryland systems (Throop and Archer 2008).

In many high desert regions of the western US, pinyon-juniper (Pinus L.-Juniperus L.) woodlands have encroached into sagebrush (Artemisia spp.) and grassland ecosystems beginning in the late $1800 \mathrm{~s}$ (Miller et al. 2008; Rowland et al. 2008). Miller and Tausch (2001) estimated that the area of pinyonjuniper woodlands has increased approximately 10-fold throughout the western US in the last 200 years, and as much as $90 \%$ of this conifer encroachment is occurring in sagebrush habitat (Miller et al. 2011). Woody encroachment in these 
systems appears to be a result of a shifting fire regime; historical fire return intervals of $\sim 10-70$ years maintained shrub steppe grasslands, while many areas have now not burned for well over 100 years (Miller and Tausch 2001). Climate change is expected to exacerbate woody encroachment in these systems (Neilson et al. 2005). Managers of federal, state, and private lands have examined many different treatment options to slow or even reverse woodland encroachment into sagebrush steppe communities including prescribed fire, mowing, chaining, cutting, mastication, and herbicide application (McIver et al. 2014). The Sagebrush Steppe Treatment Evaluation Project (SageSTEP), established in 2005 and funded through the Joint Fire Sciences Program, was planned to provide information on outcomes of alternative treatments on woody plant management in sagebrush steppe ecosystems and to provide insight on cost and public acceptance of these different management practices (McIver and Brunson 2014; McIver et al. 2014). These removal experiments provide a unique opportunity to examine the impact of woody plant encroachment, and subsequent removal, on ecosystem C pools.

Existing work on woody encroachment in high desert ecosystems suggests positive impacts on aboveground $\mathrm{C}$, but has yielded inconclusive information on both total SOC responses and the relative importance of SOC-responses in the context of comprehensive ecosystem C pools. For example, Campbell et al. (2012) used aerial photography to estimate the average aboveground $\mathrm{C}$ accumulation in undisturbed juniper woodlands as $2.9 \mathrm{~kg} \mathrm{C} \mathrm{m}^{-2}$ year $^{-1}$, but did not include estimates of the impacts on SOC stores. Rau et al. (2011), focusing on inter-tree canopy areas, measured belowground organic $\mathrm{C}$ changes associated with woodland expansion in 13 woodland sites across the US Great Basin, concluding that while woodland expansion altered the vertical distribution of both root $\mathrm{C}$ and surface SOC, woodland expansion into sagebrush ecosystems would have limited potential to significantly change total pools of belowground organic $\mathrm{C}$ in intercanopy areas. However, significant stores of SOC in semi-arid systems can be found underneath encroaching woody plant canopies relative to intercanopy areas (Neff et al. 2009; Throop et al. 2013). Enhanced C storage due to woody encroachment-or losses due to brush management-have the potential to influence regional-to-continental $\mathrm{C}$ pools
(King et al. 2007; Pacala et al. 2001; Woodbury et al. 2007). However, few comprehensive ecosystem C assessments exist in woody encroached drylands, in part due to high spatial variability of $\mathrm{C}$ in these systems and lack of existing inventory data for constructing comprehensive ecosystem $\mathrm{C}$ pools.

The objective of this study was to assess changes in comprehensive ecosystem $\mathrm{C}$ pools with woody encroachment and managed removal of junipers in a high desert sagebrush ecosystem. We aimed in particular to assess the relative importance of surface SOC pools relative to other ecosystem $\mathrm{C}$ pools, while accounting for subcanopy patterns of surface SOC and litter $\mathrm{C}$ in time and space. This approach was possible due to access to a unique site in which brush management occurred 7 years prior to sampling and a wide age/size distribution of live and dead junipers existed, giving us an opportunity to look at fine-scale spatial patterns of surface SOC and litter associated with juniper size and brush management. We hypothesized that (1) surface SOC and litter C would increase with juniper size and decrease with distance from the bole, but that litter $\mathrm{C}$ would be more sensitive to subcanopy spatial position and juniper size than surface SOC, (2) woody encroachment would lead to a net increase in ecosystem $\mathrm{C}$, with the majority of this change accounted for in aboveground live biomass pools, (3) brush management would lead to rapid degradation of aboveground pools, with slow degradation of surface and deep SOC pools. A secondary objective of this study was to develop an approach for assessing changes in $\mathrm{C}$ pools through space and time that could be applied at dryland sites in the context of land cover and management changes.

\section{Methods}

\section{Study overview}

Within the greater SageSTEP experiment, the "woodland" experiment examines biotic consequences of pinyon pine and juniper expansion at 14 higherelevation sites located in five states in the western US. We chose one site, Walker Butte, Oregon (43.52634 ${ }^{\circ}$, $-120.66870^{\circ}$ ) for our analyses. Walker Butte is a high desert sagebrush steppe system with native vegetation dominated by mountain big sagebrush (Artemisia tridentata ssp. vaseyana), squirreltail 
(Elymus elmoides), Idaho fescue (Festuca idahoensis), and Thurber needlegrass (Achnatherum thurberianum) (McIver et al. 2014). Like much of the similar landscape in the western US, woody encroachment in the study area has occurred over the past $\sim 150$ years (Miller et al. 2008); the dominant woody species is now western juniper (Juniperus occidentalis). Mean annual precipitation is $259 \mathrm{~mm}$ (McIver et al. 2014). Estimated mean annual temperature is $6.2^{\circ} \mathrm{C}$ with mean minimum temperature of $-2.7^{\circ} \mathrm{C}$ and mean maximum temperature of $15.0^{\circ} \mathrm{C}$ (means for 1895-2015; PRISM Climate Group, Oregon State University, http://prism.oregonstate.edu, accessed 6 October 2016). Elevation is $1370-1430 \mathrm{~m}$ above sea level, with a mean slope of around 3\%. Soils are ashy, glassy, frigid Vitritorrandic Durixerolls developed on volcanic ash and loess over basalt residuum (Rau et al. 2011). While research at Walker Butte has centered around the SageSTEP study (McIver and Brunson 2014), existing research on western juniper in the surrounding environment provides considerable basic ecological information regarding this species.

SageSTEP treatments were established at Walker Butte in 2006. We used two designated treatment areas for our research. One $\sim 24$ ha area (hereafter 'live juniper') serves as a control where live junipers remain intact and $\mathrm{a} \sim 20$ ha area (hereafter 'cut juniper') was felled mechanically, with felled material left on the plot. A fire treatment was applied to a separate area and a set of subplots were designated for additional treatments and repeated measurements; we worked outside these other treatment areas.

Field soil and litter collection

Fieldwork for this study took place in June 2013. We designated six 'soil C' subplots (25 m diameter) in the live juniper plot. Within each of the subplots, we selected six focal junipers that spanned the size gradient of individuals present. Among the six subplots, we obtained a fairly continuous size distribution of 36 individuals ranging from 4 to $100 \mathrm{~cm}$ stem basal diameter. We used data collected on these individuals (basal diameter, canopy diameter, and height) to establish allometric relationships among these variables. We followed the same procedure in selecting 36 cut junipers in six 'soil C' subplots within the cut juniper plot. However, we selected cut junipers based on basal diameter alone. A linear allometric relationship between basal diameter and canopy diameter for the live junipers in the control plot [canopy diameter $(\mathrm{m})=0.093 *$ basal diameter $\left.(\mathrm{cm})+0.76 ; \mathrm{r}^{2}=0.84\right]$ allowed us to estimate canopy diameter for the cut junipers.

For each of the cut and live focal junipers we collected soil cores along two transects radiating out from the bole. The direction of the first transect was randomized and the second transect was $180^{\circ}$ from the first. Soil cores $(1.7 \mathrm{~cm}$ diameter, $10 \mathrm{~cm}$ depth) were collected at six points for each transect: next to the bole; $1 / 3,2 / 3$, and $3 / 3$ of the bole-to-dripline distance; an intercanopy area beyond the dripline (with grass or bare ground; hereafter 'intercanopy'); and at the canopy mid-point of the closest A. tridentata shrub (hereafter 'sagebrush'). Distances were based on measured canopy diameter for live juniper or estimated canopy diameter for cut juniper. Sampling transects for cut juniper were oriented to avoid dense debris piles. The depth of the litter layer was measured prior to sampling; litter was brushed aside to expose mineral soil prior to sampling. The two replicate cores at each transect location $\times$ juniper combination were composited together $(\mathrm{N}=6$ collection points/juniper $\times 36$ focal junipers/treatment area $\times 2$ treatment areas $=432$ composited soil samples).

At a subset of coring locations, the litter layer was collected to characterize litter density and $\mathrm{C}$ content. Litter was collected by removing all material in a quadrat $(30 \mathrm{~cm} \times 30 \mathrm{~cm}$ in most cases, but smaller quadrats were used when necessary on small junipers). Mean litter depth for each quadrat was recorded. Litter and soil samples were air dried in the field and oven dried at $60{ }^{\circ} \mathrm{C}$ upon arrival in the laboratory.

Soil and litter samples were analyzed for bulk density and C content. Soil samples were passed through a $2 \mathrm{~mm}$ sieve. Bulk density was determined as the mass of the $<2 \mathrm{~mm}$ fraction divided by the volume of the entire core; rock volume was not excluded in order to avoid overestimating soil $\mathrm{C}$ content due to not accounting for rock displacement (Throop et al. 2012). Remaining roots or litter that passed through the sieve were removed manually from soil subsamples. Soil subsamples were pulverized on a ball mill. Organic $\mathrm{C}$ content of these subsamples was determined by acid fumigating samples to remove inorganic C (Harris et al. 2001) followed by $\mathrm{C}$ and $\mathrm{N}$ determination by combustion (ECS 4010, Costech Analytical Technologies, Inc., Valencia, CA, USA). 
Litter bulk density was calculated as the dry mass of litter quadrat samples divided by the sample volume (litter quadrat area multiplied by litter depth). Litter samples were pulverized in a ball mill and analyzed for $\mathrm{C}$ and $\mathrm{N}$ content by combustion.

Carbon pool calculations: individual junipers

Surface SOC under juniper canopies was modeled based on measured surface SOC and litter C to take into account spatial patterns along bole-to-dripline gradients and with juniper size (Throop and Archer 2008). Mixed-effects models (lme4 package in R; Bates et al. 2015) were used to find the best fit model for soil bulk density as a function of basal diameter, core position, and the square of core position (allowing linear analysis of a non-linear model). Each individual juniper was included as a random factor. The model was run with all possible combinations of predictive variables and AIC was used to select the best fit soil bulk density models. For the selected models, marginal $r^{2}\left(r_{m}^{2}\right)$ and conditional $r^{2}\left(r_{c}^{2}\right)$ values were calculated, where marginal values are associated with fixed effects and conditional values are associated with fixed plus random effects (Nakagawa and Schielzeth 2012). Separate soil bulk density models were fitted for cut and live juniper canopy areas. These soil bulk density models were used to predict bulk density at each coring location. Bulk density is an inherently variable measurement (e.g., a pebble, root, or soil macropore can cause large differences in measured bulk density for any given core). Using modeled bulk density rather than actual bulk density at each coring location minimizes the impact of this variability on calculated SOC at any given location. Homogenizing this variability is most appropriate given that it is not expected the change with juniper size or coring location.

Surface SOC $\left(\mathrm{g} \mathrm{C} \mathrm{m}^{-2}\right)$ at each coring location was calculated as a function of modeled bulk density and measured SOC concentration ( $\mathrm{mg} \mathrm{C} \mathrm{g}^{-1}$ soil). Total litter $\mathrm{C}\left(\mathrm{g} \mathrm{C} \mathrm{m}^{-2}\right)$ at each coring location was calculated from litter depth $(\mathrm{cm}$, mean of the two measured litter depths at each juniper $\times$ core position combination), litter bulk density (litter $\mathrm{g} \mathrm{cm}^{-3}$; calculated as described above), and litter $\mathrm{C}$ concentration (mg C g ${ }^{-1}$ litter). Spatial patterns of surface SOC and litter $\mathrm{C}$ responses to juniper size and core position were assessed using the same mixed-model approach as was used for bulk density. Total subcanopy surface SOC for individual junipers was estimated by integrating the sub-canopy surface SOC equations as the volume of a solid of revolution, where the limits were the outer edge of the bole and the canopy dripline (Throop and Archer 2008). Core position was converted to absolute distance to allow integration. Integration was performed using Maple 16 (Maplesoft, Waterloo, ON, Canada). The same procedure was used for estimating subcanopy litter C.

We took advantage of extensive prior work with $J$. occidentalis carried out in geographic proximity to our study site to estimate $\mathrm{C}$ pools for individual junipers based on our basal diameter measurements. We estimated aboveground juniper biomass (stem, live and dead branches, and leaf) from allometric relationships developed for J. occidentalis ca. $50 \mathrm{~km}$ from our study area (Gholz 1980). Aboveground biomass was multiplied by 0.4564 to convert to aboveground $\mathrm{C}$ (Fernandez et al. 2013). Root C was estimated as $59.8 \%$ of aboveground $\mathrm{C}$ for each juniper, based on measured root:shoot ratio for J. occidentalis at a nearby study location (Krämer et al. 1996). Root C mass is the estimated for the entire tree, and not partitioned by depth. We used published data from a nearby field site with similar climate conditions (Klemmedson and Tiedemann 2000) to estimate tree age from basal diameter [age (years) $=0.41 *$ basal diameter $\left.(\mathrm{cm})+2.54 ; \mathrm{r}^{2}=0.94\right]$. The allometric studies used took place within $90 \mathrm{~km}$ and $350 \mathrm{~m}$ elevation of our site, with similar climate conditions and on volcanically-derived soils (Supplemental Table 1). The biomass to $\mathrm{C}$ conversion was based on data for J. osteosperma from an upland shallow loam black sagebrush community in the Colorado Plateau (Fernandez et al. 2013) as we could not find data from more closely located Juniperus studies. This value is within the realm typical of woody species (Lamlom and Savidge 2003). A disadvantage of using published relationships in the literature is that error is often not presented with regression equations, limiting the assessment of uncertainty. We consequently were unable to propagate error with our modeled $\mathrm{C}$ pool calculations, and we present data without uncertainty analyses. 
Landscape-scale C pools

We estimated juniper canopy cover in six 'juniper cover' subplots in each of the two management areas (live and cut) in order to scale our $\mathrm{C}$ pool results up to estimate landscape-scale C pools. Subplots were $25 \mathrm{~m}$ in radius; there were five semi-circular subplots $\left(982 \mathrm{~m}^{2}\right.$ each) and one circular subplot $\left(1964 \mathrm{~m}^{2}\right.$ each) in each of the two management areas. All live or cut junipers in the juniper cover subplots were censused and measured for canopy diameter (live junipers) or basal diameter (cut junipers). The allometric relationship between basal diameter and canopy diameter established previously (see "Field soil and litter collection" section) was used to estimate canopy diameter for the cut junipers. The number and size of individuals from the juniper surveys were used to estimate woody cover and above- and belowground $\mathrm{C}$ pools for the two management areas.

We estimated landscape-scale $\mathrm{C}$ pools under different vegetation cover scenarios. While the live and cut juniper areas had similar juniper density (250 and 243 individuals $\mathrm{ha}^{-1}$, respectively; $F_{1,10}=0.03$, $P=0.86$ ), total juniper cover was slightly lower in the live area than the cut area (13.4 and $18.3 \%$, respectively; $F_{1,10}=9.92, P=0.01$ ). To prevent these differences in cover from masking differences in juniper impacts on $\mathrm{C}$ pools, we estimated $\mathrm{C}$ pools for hypothetical live and cut management areas. Each of these hypothetical management areas included all junipers in the six juniper cover subplots from each of the two management areas, thus allowing us to estimate impacts of management treatments on landscape-scale $\mathrm{C}$ pools without having our results affected by pre-existing differences in juniper cover between the two management areas. We estimated $\mathrm{C}$ pools based on the distribution of juniper sizes in the juniper cover subplot data, but used assumptions of different relative cover for shrubs and juniper. We estimated $\mathrm{C}$ pools at different hypothetical time periods when relative cover of open, sagebrush, and juniper was expected to differ (Table 1). Landscape $C$ compilations included surface SOC $(0-10 \mathrm{~cm})$, deep SOC $(10-90 \mathrm{~cm})$, litter C, juniper aboveground C, and juniper root $\mathrm{C}$. Non-juniper live and dead biomass (e.g., herbaceous vegetation and A. tridentata) were not included in landscape-scale $\mathrm{C}$ pools due to the small contribution of this vegetation to landscape $\mathrm{C}$ pools. Carbon pools were estimated for each scenario by multiplying proportional area of each cover type by the $\mathrm{C}$ mass per area of each $\mathrm{C}$ pool. Subcanopy surface SOC and litter $\mathrm{C}$ pools values were obtained using $\mathrm{C}$ mass per area from the integration model, summing up $\mathrm{C}$ data from all individuals present. Surface SOC in intercanopy areas and below sagebrush canopies were based on the mean values from soil cores. For the cut juniper scenario, juniper $\mathrm{C}$ was adjusted for decomposition in the 7 years following cutting. Leaf biomass was assumed to be zero based on observations that no leaf material persisted on felled junipers. Wood and root biomass were assumed to decrease with time, but due to lack of site-relevant existing data we used rates derived from global syntheses. Wood decay was modeled with a decay constant based on mean annual temperature from a synthesis of global wood decay studies ( $k=0.0325$ year $^{-1}$; Russell et al. 2015). Root decay was based on the mean value for conifer roots of all size classes from a global synthesis ( $k=0.3$ year $^{-1}$; Silver and Miya 2001). We used the mean value for conifer roots as, while environmental factors have some control over root decay rates, these factors appear to be of secondary importance to root chemistry, which is associated with plant life form (Silver and Miya 2001). Deep SOC (10-90 cm) was calculated as the mean of values presented from a previous study at this site $\left(76.95 \mathrm{Mg} \mathrm{ha}^{-1}\right.$; Rau et al. 2011), where there were no differences in deep SOC among different vegetation cover areas. We did not calculate confidence intervals for landscape-scale C pool projections due to lack of available error information from our data sources.

\section{Results}

Spatial patterns of juniper subcanopy surface SOC

There were strong subcanopy spatial patterns in surface SOC and litter $\mathrm{C}$ relative to juniper basal diameter. The best fit model for juniper subcanopy surface SOC was a linear model where surface SOC responded positively to basal diameter and negatively to distance from the bole in both live and cut treatment areas (Fig. 1a, b, Supplemental Table 2; $\mathrm{SOC}_{\text {live }}=$ $2058.9+17.7 *$ basal $-249.7 *$ core,$\quad r_{m}^{2}=0.31$, $\mathrm{r}_{\mathrm{c}}^{2}=0.58, \quad$ and $\quad \mathrm{SOC}_{\mathrm{cut}}=1912.2+22.2 *$ basal $-192.3 *$ core where basal is basal diameter in $\mathrm{cm}$ and core is canopy position with position 
Table 1 Scenarios for percent cover of mountain big sagebrush (Artemisia tridentata ssp. vaseyana) shrubs and western juniper (Juniperus occidentalis) used for landscape-scale C estimates

\begin{tabular}{|c|c|c|c|c|}
\hline Scenarios & Description & $\begin{array}{l}\text { Shrub cover } \\
(\%)\end{array}$ & $\begin{array}{l}\text { Juniper cover } \\
(\%)\end{array}$ & $\begin{array}{l}\text { Open cover } \\
(\%)\end{array}$ \\
\hline Sagebrush & $\begin{array}{l}\text { Assumed pre-encroachment conditions with sagebrush present but } \\
\text { no juniper }\end{array}$ & 3.5 & 0 & 96.5 \\
\hline 2013 Live & Juniper cover as measured in 2013 ; all trees live & 3.0 & 15.8 & 81.2 \\
\hline 2013 Cut & $\begin{array}{l}\text { Juniper cover as measured in 2013; all trees cut in } 2005 \text { brush } \\
\text { management treatment }\end{array}$ & 3.0 & 15.8 & 81.2 \\
\hline $\begin{array}{l}\text { Double } \\
\text { juniper }\end{array}$ & Juniper cover doubled from that measured in 2013 & 2.5 & 31.6 & 65.9 \\
\hline $\begin{array}{l}50 \% \text { Juniper } \\
\text { cover }\end{array}$ & Juniper cover nearing assumed maximum cover for this region & 2.0 & 50.0 & 48.0 \\
\hline
\end{tabular}

Sagebrush cover in the 2013 scenarios was based on published values for this field site while juniper cover was measured for this study. Sagebrush cover in the other scenarios was adjusted based on assumed proportional displacement of open area. Open cover is defined as anything without woody cover (e.g., bare ground or grass)

$1=$ bole and position $4=$ dripline; $\mathrm{r}_{\mathrm{m}}^{2}=0.34$, $\left.r_{c}^{2}=0.53\right)$. Patterns for litter $C$ for live and cut juniper were similar to surface SOC, although the best fit model included the square of canopy position rather than a linear model (Fig. 1c, d, Supplemental Table 2; LitterC $_{\text {live }}=3680.8+40.7 *$ basal $-268.5 *$ core $^{2}$, $\mathrm{r}_{\mathrm{m}}^{2}=0.54, \mathrm{r}_{\mathrm{c}}^{2}=0.78 \quad$ and $\quad$ LitterC $_{\text {cut }}=2816.4+$ $31.6 *$ basal $-204.2 *$ core $\left.^{2}, \mathrm{r}_{\mathrm{m}}^{2}=0.44, \mathrm{r}_{\mathrm{c}}^{2}=0.64\right)$.

Individual-scale $\mathrm{C}$ pools

We used integrated subcanopy surface SOC and litter $\mathrm{C}$ pools, modeled aboveground and root $\mathrm{C}$ pools, and estimated juniper ages to assess changes in $\mathrm{C}$ pools with juniper age/size. On a per-area basis, aboveground $\mathrm{C}$ and root $\mathrm{C}$ for live junipers increase with increasing basal diameter (Fig. 2a). Subcanopy surface SOC increased nearly linear with basal diameter when expressed on a per area basis $\left(\mathrm{g} \mathrm{C} \mathrm{m}^{-2}\right)$. In contrast, litter $\mathrm{C}$ exhibited a rapid increase for junipers $<20 \mathrm{~cm}$ and a less steep linear response thereafter (Fig. 2b). Algorithms relating basal diameter to juniper age suggest that the largest live junipers in the study area were ca. 44 years old.

Modeled litter pools ( $\mathrm{g}$ litter $\mathrm{C} \mathrm{m}^{-2}$ ) declined in the 7 years after junipers were cut, with the magnitude of the decline greater for larger junipers (Fig. 3). In contrast, subcanopy surface SOC $\left(\mathrm{g} \mathrm{C} \mathrm{m}^{-2}\right)$ increased linearly with basal diameter, except for very small trees. The net effect of cutting on surface $\mathrm{C}$ (litter + surface SOC) was for a loss of C (Fig. 3). This loss increased with increasing basal diameter until about $25 \mathrm{~cm}$, at which point it stayed relatively stable at around $400 \mathrm{~g} \mathrm{C} \mathrm{m}^{-2}$ lost with cutting (Fig. 3).

Landscape-scale C pools

When $\mathrm{C}$ pools were scaled up to the landscape-scale based on measured 2013 sagebrush and juniper distribution and hypothetical future vegetation cover scenarios, deep SOC $(10-90 \mathrm{~cm})$ dominated C pools under all vegetation cover scenarios $\left(77.0 \mathrm{Mg} \mathrm{C} \mathrm{ha}^{-1}\right.$, Fig. 4). Excluding deep SOC, other C pools more than doubled with juniper encroachment into the system (13.5-30.2 Mg C ha ${ }^{-1}$ for 'sagebrush' and '2013 live' scenarios, Fig. 4). While this increase was largely a function of juniper root and aboveground $\mathrm{C}$, increases in juniper root $\mathrm{C}$ and juniper surface $\mathrm{SOC}$ together accounted for $7.6 \mathrm{Mg} \mathrm{C} \mathrm{ha}^{-1}$. Landscape-scale C pools were reduced by cutting juniper (2013 cut scenario), but this was largely due to a decrease in juniper aboveground and root $\mathrm{C}$. Litter $\mathrm{C}$ and surface SOC pools remained largely unchanged 7 years after cutting. With hypothetical increases in juniper cover under the continued encroachment scenarios, there were substantial increases in landscape $\mathrm{C}$ pools (up to 145.6 $\mathrm{Mg} \mathrm{C} \mathrm{ha}{ }^{-1}$ for the $50 \%$ juniper cover scenario). This continued increase in landscape $C$ was primarily in the juniper aboveground $\mathrm{C}$ and $\operatorname{root} \mathrm{C}$ pools (increase of 26.1 $\mathrm{Mg} \mathrm{C} \mathrm{ha}{ }^{-1}$ from 2013 live to $50 \%$ juniper cover scenario), but there was also substantial increase in the juniper surface SOC and litter pools (7.1 and 9.9 $\mathrm{Mg} \mathrm{C} \mathrm{ha}^{-1}$, respectively). 

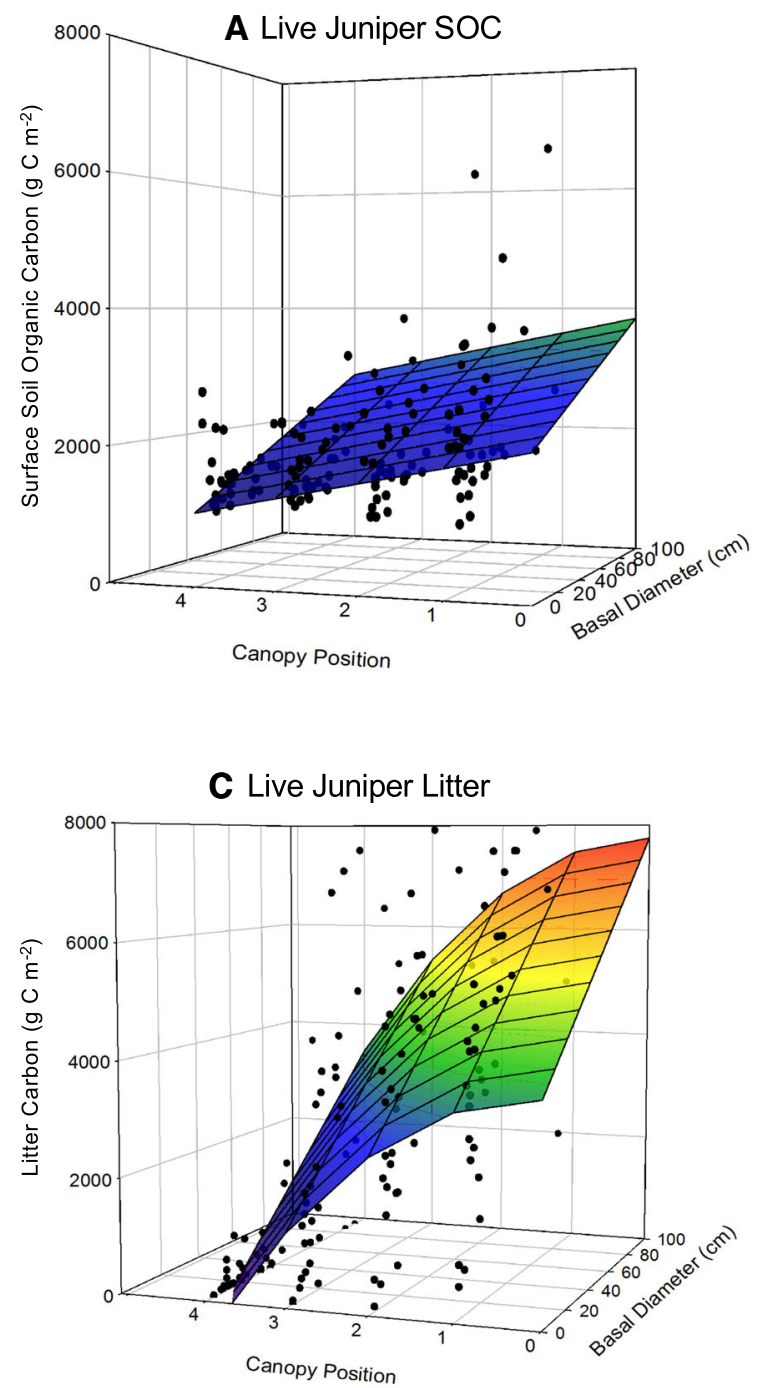

Fig. 1 Measured and modeled surface (top $10 \mathrm{~cm}$ ) soil organic carbon for a live juniper and $\mathbf{b}$ cut juniper and litter $\mathbf{C}$ for $\mathbf{c}$ live juniper and $\mathbf{d}$ cut juniper at Walker Butte SageSTEP. Points are measured values from soil cores and litter measurements from 36 trees for each of the two treatments. At each tree, composite samples from two cores were analyzed at four canopy positions

\section{Discussion}

Woody encroachment influences on surface carbon pools

Our results indicate that juniper encroachment in eastern Oregon increases surface SOC and litter C storage at multiple spatial scales. Supporting our hypothesis, surface SOC increased with juniper size and decreased with distance from the bole. When these
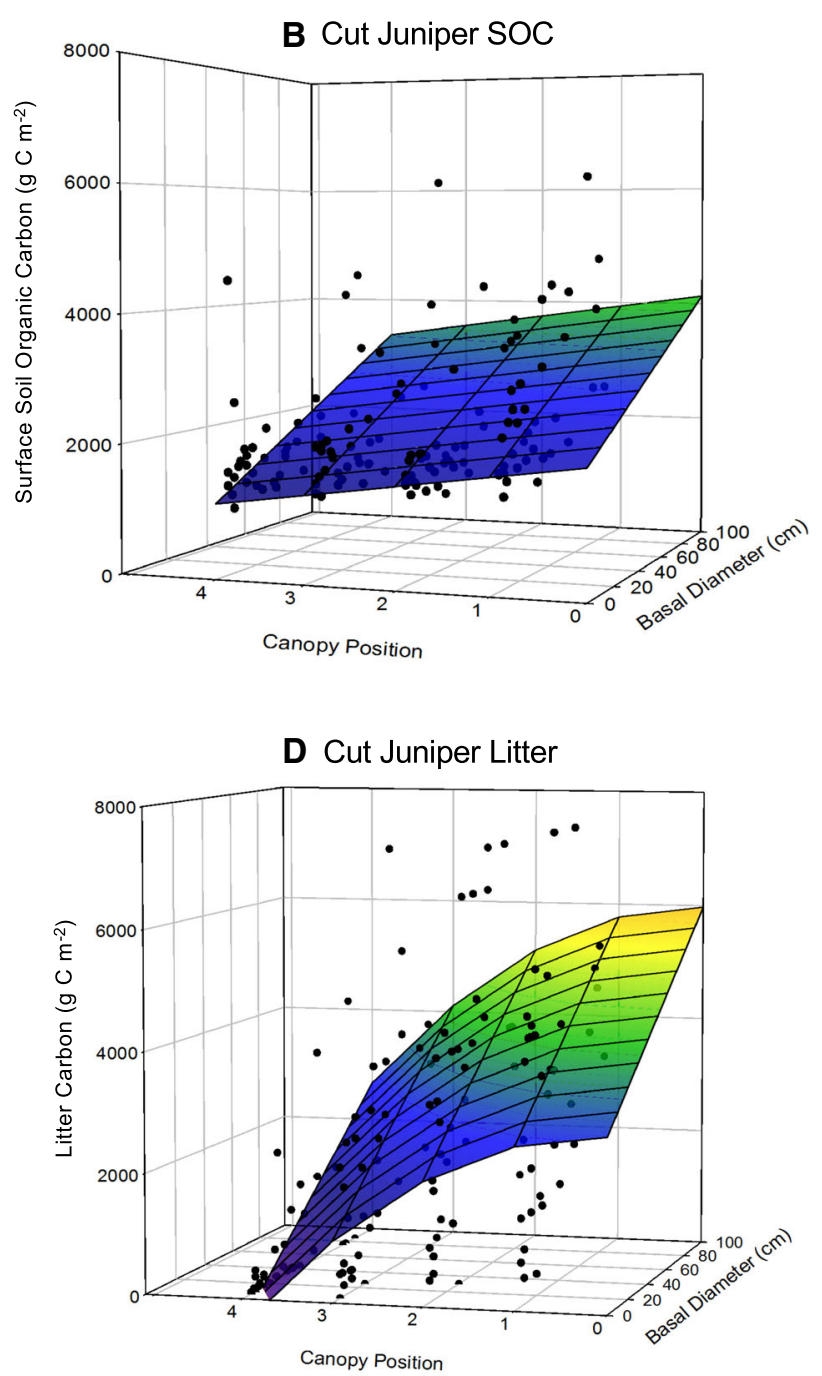

( $1=$ bole, $2=1 / 3$ bole to dripline distance, $3=2 / 3$ bole to dripline distance, $4=$ dripline) for SOC measurements. The three dimensional surfaces are best fit models that take basal diameter and canopy position into account; these surfaces are used to predict total surface SOC and litter $\mathrm{C}$ under junipers of known size

patterns were scaled up to individual tree subcanopies, juniper increased mean surface SOC more than $600 \mathrm{~g} \mathrm{C} \mathrm{m}^{-2}$ relative to open areas. Reports of juniper impacts on surface SOC are extremely variable among sites. For example, J. virginiana encroachment in Kansas, USA increased SOC in the top $10 \mathrm{~cm}$ by only about $12 \%$ (McKinley and Blair 2008), much less than the $47 \%$ surface SOC increase in our study. In contrast, top $10 \mathrm{~cm}$ SOC was five times greater under trees than in canopy interspace areas in a pinyon- 


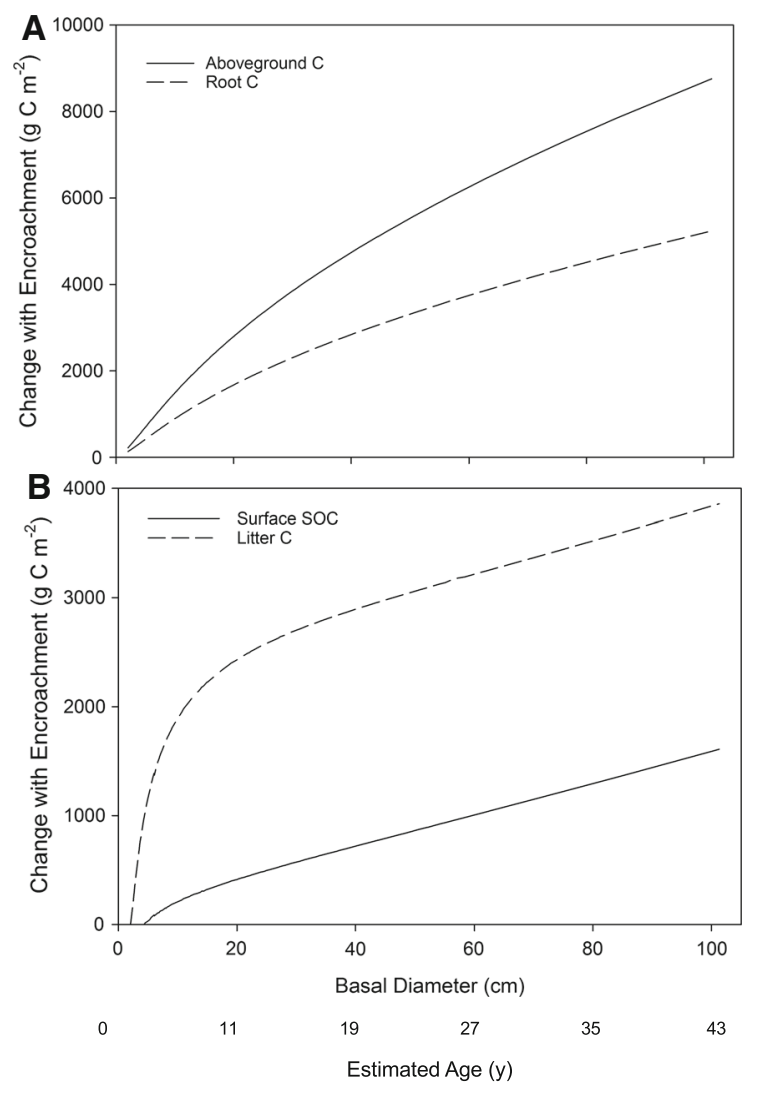

Fig. 2 Modeled change in carbon pools with woody encroachment for individual juniper of different basal diameters. a Aboveground $\mathrm{C}$ (juniper wood and leaf $\mathrm{C}$ ) and root $\mathrm{C}$ (throughout the soil profile) were estimated from allometric relationships between basal diameter and aboveground biomass and root:shoot ratios (see "Methods" section). b Surface soil organic C (SOC; top $10 \mathrm{~cm}$ of soil) and litter C represent the difference between subcanopy SOC values from integration models and background SOC and litter $\mathrm{C}$ for open areas. Juniper age estimates are based on tree ring data from a nearby site (see "Methods" section)

juniper woodland in southern Utah, USA (Neff et al. 2009), perhaps a function of less moisture limitation to plant production at the UT site relative to our study site (360 and $259 \mathrm{~mm}$ MAP, respectively). Another possible factor in among-study variability in SOC response to woody encroachment is the lack of consistent protocols for accounting for subcanopy spatial patterns. The observed spatial patterns in SOC under juniper canopies suggests that the specific location where sub-canopy cores are obtained will influence conclusions regarding encroachment impacts on SOC pools. This leads to the possibility for over- or underestimating SOC response to woody

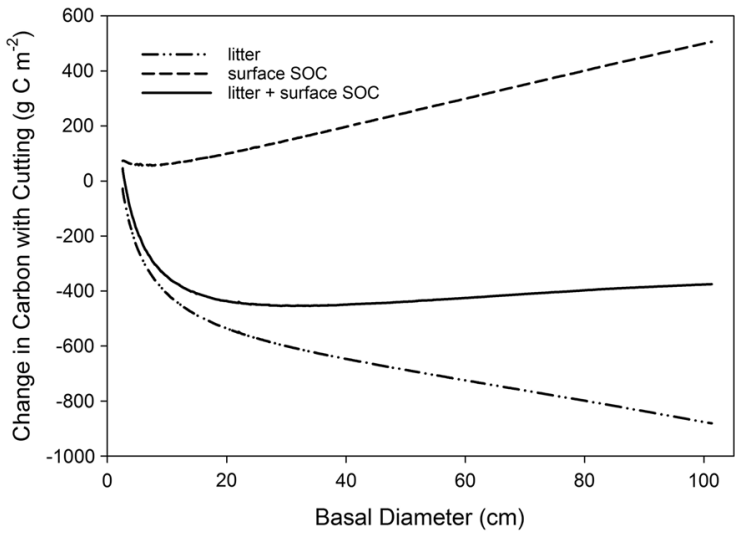

Fig. 3 Modeled change in carbon pools 7 years after juniper were cut for brush management. Changes in litter $\mathrm{C}$, surface soil organic carbon (SOC; top $10 \mathrm{~cm}$ of soil), and combined litter + surface SOC pools $\left(\mathrm{g} \mathrm{m}^{-2}\right)$ are estimated for juniper of different basal diameters. Curves were generated as the difference in litter and surface SOC pools between live and cut juniper of a given basal diameter. Litter and surface SOC pools for individual juniper were based on integration of litter and surface SOC models (Fig. 1)

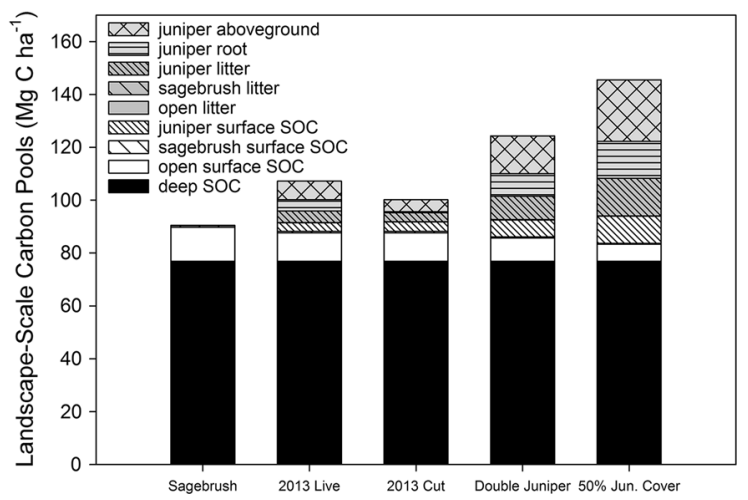

Fig. 4 Landscape-scale carbon pools that combine estimates of vegetation cover and $\mathrm{C}$ mass per area for each of the vegetation cover scenarios described in Table 1. "Sagebrush" is a prewoody encroachment scenario where there is no juniper cover. The conditions at the time of sampling are represented by "2013 Live" in the uncut area and "2013 Cut" in the cut area. The "Double Juniper" scenario represents double the 2013 juniper cover and " $50 \%$ Jun. Cover" represents an extreme encroachment scenario where juniper cover is $50 \%$

encroachment if spatial patterns are not considered. Our data suggest that the core 3 position (2/3 of distance from bole to dripline) best represents the average subcanopy position, accounting for the small area of high surface SOC concentration near the bole and the much larger area of relatively low surface SOC concentration away from the bole. Sampling time and 
analytical costs are prohibitive for frequent characterization of sub-canopy spatial patterns, but knowledge of these patterns will allow selection of appropriate coring locations that represent mean subcanopy values.

Quantifying surface SOC patterns for woody plants of different sizes provides an opportunity to infer temporal changes in SOC with growth. The positive relationship between woody plant size and SOC pool size indicates SOC accumulation over time. In contrast to the logarithmic response of surface SOC to basal diameter described by Throop and Archer (2008), we found a linear response. This difference was driven by a stronger decline in SOC for very small shrubs in the Throop and Archer (2008) study, which could be a function of higher rates of surface erosion at that site for small shrubs than larger shrubs (Throop and Archer 2007). Alternatively, it could be that the present study did not have a sufficient number of very small junipers to capture deviations from the linear relationship for these individuals. We do not have long-term growth records or dendrochronology data from this site that would be needed to directly determine ages of sampled live and cut junipers. However, relationships between juniper age (estimated from tree rings) and basal diameter established near our study site (Klemmedson and Tiedemann 2000) suggest that the largest of our sampled junipers were ca. 44 years old. Modeled mean subcanopy surface SOC increased $1609 \mathrm{~g} \mathrm{C} \mathrm{m}^{-2}$ under a 44 -year-old $(101 \mathrm{~cm}$ basal diameter) juniper relative to open conditions, equivalent to a $36.6 \mathrm{~g} \mathrm{C} \mathrm{m}^{-2}$ year $^{-1}$ accumulation rate. However, landscape level accumulation rates would be much lower given the relatively low woody cover of this system.

Litter C data supported our hypothesis that litter C would increase with juniper size and decrease with distance from the bole. Increasing leaf area index towards the bole and with larger junipers canopies could explain, at least in part, these spatial patterns. Litter spatial patterns may also be reinforced by surface transport processes where accumulation is enhanced towards the bole and under larger canopies (Barnes et al. 2015) and with corresponding slow subcanopy litter decomposition due to litter chemistry and juniper microclimate effects (Norris et al. 2001; Throop et al. 2017). As we hypothesized, litter C was more sensitive to sub-canopy spatial position and juniper size than surface SOC. However, belowground inputs are thought to be more important to SOC accumulation than aboveground inputs (Rasse et al. 2005). We expect that root biomass distribution is likely to be more homogeneous than aboveground biomass distribution, supporting the disconnect between above and belowground $\mathrm{C}$ distribution patterns. However, we did not measure root biomass in our collected soil cores and thus cannot assess the extent to which SOC accumulation may be driven by spatiotemporal patterns of root distribution.

Carbon in juniper litter contributed a large and dynamic portion of the total $\mathrm{C}$ from juniper encroachment, accounting for $26 \%$ of the observed ecosystem $\mathrm{C}$ increase. Litter $\mathrm{C}$ changes following woody encroachment are reported less frequently than surface SOC changes; lack of consideration of this pool may underestimate woody encroachment impacts on ecosystem $\mathrm{C}$ pools. The magnitude of the litter pool response to woody encroachment is in part a function of the near absence of a litter pool in open areas (mean open litter $=2 \mathrm{~g} \mathrm{C} \mathrm{m}^{-2}$; mean live juniper litter $=2788 \mathrm{~g} \mathrm{C} \mathrm{m}^{-2}$ ). Similar contrasts with juniper encroachment were found in a $J$. virginiana-encroached forest in Kansas, USA, where there was $1540 \mathrm{~g} \mathrm{C} \mathrm{m}^{-2}$ in the litter layer versus no litter layer in a neighboring unencroached grassland (McKinley and Blair 2008).

Brush management influences on surface carbon pools

Brush management had a little impact on surface SOC pools when we measured responses 7 years after the treatment, with an overall slight increase in subcanopy SOC following brush management. This limited impact of brush management on surface SOC mirrors results found in southern Arizona with Prosopis velutina, where surface SOC under shrubs killed 8 years prior to sampling did not differ from that under live shrubs (DeMarco et al. 2016). In contrast, at the same site in Arizona, brush management 40-52 years prior to soil sampling led to $>50 \%$ SOC loss in soil layers up to $20 \mathrm{~cm}$ deep (DeMarco et al. 2016; McClaran et al. 2008). The lack of degradation of the surface SOC could reflect a pool of mineral-stabilized SOC that may be present even in sandy soils with limited C stabilization capacity (DeMarco et al. 2016). Alternatively, it may be that apparent SOC stability reflects long-term litter inputs from juniper mortality 
that counterbalance losses of surface SOC. The observed reduction in the litter layer beneath cut juniper canopies suggests that litter degradation and transfer of decomposition products to the surface soil layer could have played a role in the lack of change in surface SOC. A large influx of litter would have occurred soon after cutting as litter dropped off the felled junipers. However, any later influx would have been from accumulation of surface-transported material; we assume this will be much lower than decay of existing litter. Thus, while surface litter may serve as a substantial C pool it would be a relatively short-term C storage pool that would be subject to loss following land management.

Although root longevity and turnover are notoriously difficult to measure (Strand et al. 2008), slow decomposition of roots from conifers relative to broadleaf trees (Zhang and Wang 2015) and coarse roots relative to fine roots (Silver and Miya 2001) suggests that significant amounts of the original root biomass will still be present in these dry soils even 7 years after tree removal. Although root $\mathrm{C}$ is thought to be preferentially retained as soil organic matter over aboveground inputs (Rasse et al. 2005), slowly decomposing coarse woody debris (Janisch et al. 2005) could also be a long-term source of C into SOC pools. Plant biomarker and stable isotope analyses of soils following brush management of $P$. velutina suggest changes in SOC occur from both decay of existing SOC and inputs from dead trees (DeMarco et al. 2016). The slow decay of roots will likely offset some native SOC mineralization and maintain relatively high levels of sub-canopy surface SOC for yearto-decades to come.

Woody encroachment and brush management influences on landscape $\mathrm{C}$ pools

Combining the surface SOC and litter C spatial models with juniper size distribution data allowed us to scale up to estimate landscape-scale $\mathrm{C}$ pools. These data supported our second hypothesis, that woody encroachment would lead to a net increase in ecosystem $\mathrm{C}$, with the majority of this change accounted for in aboveground live biomass pools. However, increasing juniper cover from the sagebrush-only scenario to the 2013 live encroached scenario increased landscape-level surface SOC by only $8 \%\left(1.1 \mathrm{Mg} \mathrm{C}^{-1}\right)$. Landscape-level surface SOC + litter C were increased by $41 \%$
(4.3 $\mathrm{Mg} \mathrm{C} \mathrm{ha}^{-1}$ ). The combined surface SOC + litter $\mathrm{C}$ increases are consistent with a prediction of a $47 \%$ increase at this MAP from a synthesis of tree encroachment impacts by Barger et al. (2011). In contrast, estimated aboveground C increase from sagebrush-only scenario to the 2013 live encroached scenario was $7.06 \mathrm{Mg} \mathrm{C} \mathrm{ha}^{-1}$, considerably less than $40.09 \mathrm{Mg} \mathrm{C} \mathrm{ha}^{-1}$ predicted for tree encroachment at this MAP by Barger et al. (2011; data converted to C mass from biomass data presented in paper). A challenge in scaling up from individual plant measurements to the landscape level is that $\mathrm{C}$ pools are often contrasted between open and encroached individuals or patches; we suggest that these patch contrasts will frequently overestimate woody plant impacts on $\mathrm{C}$ pools. Many of the studies synthesized in Barger et al. (2011) are patch-level comparisons where the size distribution of individual woody plants may not be taken into account; sampling that is not carefully sizestratified is likely to overestimate $\mathrm{C}$ pools given the relatively limited influence that small woody plants have on $\mathrm{C}$ pools.

As we hypothesized, aboveground $\mathrm{C}$ emerged as a major component of the total $\mathrm{C}$ pool response to juniper encroachment. Prior studies with juniper encroachment and removal have yielded mixed results as to whether understory vegetation (grasses and shrubs) responds positively (Miller et al. 2014; Roundy et al. 2014), negatively (Fernandez et al. 2013), or does not respond strongly to changes in juniper presence and size (Tiedemann and Klemmedson 2000). Regardless of the net change, understory plants account for a very small portion of system $\mathrm{C}$ (Tiedemann and Klemmedson 2000). In contrast, our $\mathrm{C}$ pool analysis suggests that juniper aboveground biomass is substantial portion of the landscape $\mathrm{C}$ pool with woody encroachment, particularly in the higher tree cover scenarios with continued encroachment (e.g., aboveground juniper $\mathrm{C}$ accounts for $6.6 \%$ of system $\mathrm{C}$ in 2013 live scenario and $15 \%$ of system $\mathrm{C}$ in the $50 \%$ juniper cover scenario).

Given the importance of aboveground $\mathrm{C}$ pools in this systems, a crucial question for assessing the longterm fate of $\mathrm{C}$ in these pools is what controls the decomposition of aboveground biomass-particularly wood-following natural mortality or brush management in drylands. We hypothesized that brush management would lead to rapid degradation of aboveground $\mathrm{C}$ pools; our estimates indicate $36 \%$ of 
aboveground $\mathrm{C}$ had declined in the 7 years following brush management. Land management activities can directly influence whether dead wood is retained in the system. In some cases, felled trees are manually removed from the site (particularly in areas where wood serves as an important cooking fuel; Vermeulen et al. 2000). Frequently aboveground biomass is not removed following juniper management in the US, although fuels reduction strategies such as mechanical mastication are sometimes used (Ross et al. 2012). Spreading of the resulting woody debris across the landscape may speed losses of $\mathrm{C}$ from the system by accelerating decay of masticated wood relative to intact wood. Standing dead juniper skeletons can persist in the landscape for decades following mortality, but we assume that on the scale of decades-tocenturies this material is decomposed and released from the system. Alternatively, it is possible that some $\mathrm{C}$ from wood is incorporated into soils and becomes stabilized, enhancing SOC pools over long time scales. We currently lack data on the long-term fate of wood decay in drylands to directly address this. However, the low microbial substrate utilization efficiency of wood suggests there should be little stable SOC formed from decaying wood (Cotrufo et al. 2013). Work in mesic systems supports this idea, with decomposing logs leading to little apparent inputs to SOC (Spears et al. 2003). Given the generally low SOC stabilization in drylands relative to mesic systems (Throop et al. 2013), we do not expect wood to contribute to substantial SOC stabilization in drylands.

Although surface SOC, litter, and aboveground pools were shaped by woody encroachment and juniper removal, it was apparent from the landscape $\mathrm{C}$ pool analysis that these aboveground and surface soil pools were dwarfed by deep SOC. Our fieldcollected data focused on the top $10 \mathrm{~cm}$ of soil as these pools are most dynamic to changes in vegetation (Jackson et al. 1996; McClaran et al. 2008; Zhou et al. 2017). Our deep SOC values were based on data from this site where no management treatment effects on SOC were reported at depths greater than $15 \mathrm{~cm}$ (Rau et al. 2011). It is important to note that this prior analysis did not explicitly consider subcanopy versus intercanopy locations; cores were collected from intercanopy areas that differed in landscape-level juniper density. However, the finding that woody encroachment would have minimal impact on deep
SOC was supported with a study on Prosopis glandulosa encroachment. Distinct tree sub-canopy spatial patterns in SOC were present in the top $15 \mathrm{~cm}$ of soil, but these disintegrated with depth (Zhou et al. 2017). While woody plant influence on SOC was concentrated in the surface soils ( $40 \%$ of the difference in the top $5 \mathrm{~cm}$ and $59 \%$ of the difference in the top $15 \mathrm{~cm}$ ), there were measurable differences with woody cover down to lowest measured depth $(120 \mathrm{~cm})$. Our expectation is that SOC accumulation will be even more restricted to the surface for $J$. occidentalis as roots appear to be largely restricted to surface soils (Miller et al. 2005), whereas $P$. glandulosa can produce extensive deep roots (Gibbens and Lenz 2001). Together, these results indicate that deep SOC pools account for a substantive portion of system SOC in semi-arid ecosystems and suggest that this deep SOC is fairly static through time and space. However, we caution that very little deep SOC data exists, particularly in dryland ecosystems. Given the large amount of SOC in deep soil pools, small changes proportional changes in deep SOC from land cover or management would have large impacts on ecosystem $\mathrm{C}$ pools. It is probable that some change in deep SOC would be detected with sufficient time following woody encroachment or with finer-scale spatial resolution (e.g., at the center of large juniper subcanopies). Further assessments of the response of deep SOC to woody encroachment and brush management are needed.

Data needs and limitations

Well-justified, comprehensive ecosystem C estimates are necessary for improving our understanding of woody encroachment and brush management impacts on local, regional, and global $\mathrm{C}$ cycling. Given high spatial variability in $\mathrm{C}$ pools, careful scaling from small-scale measurements up to landscape-scale $\mathrm{C}$ is needed. Our spatiotemporal models of surface SOC and litter $\mathrm{C}$ indicate that these pools are dynamic in time and space; spatially-limited coring efforts therefore run a risk of under- or overpredicting $\mathrm{C}$ pools (Throop and Archer 2008). However, the large number of samples needed for developing these relationships makes these assessments unrealistic for routine $\mathrm{C}$ inventory or management assessments. Similar information from other site is needed to assess the generalizability of these relationships. In particular, 
observed patterns may differ considerably with climate and edaphic conditions, woody species, and management activities. Likewise, with only one point in time following brush management we are limited in understanding how $\mathrm{C}$ pools, and their spatial patterns, will change with time following brush management. Given the importance of spatial patterns and large uncertainty in existing information, we suggest that compilation of similar data from a range of woody species, edaphic conditions, and climate regimes will facilitate development of more generalizable models across space and time.

Our scaling approach for juniper and deep soil C pools required a large number of assumptions. Prior research with juniper in close geographic proximity to Walker Butte made this scaling possible, although use of data from other sites introduces unquantifiable uncertainty. For example, values for juniper aboveground biomass, root:shoot, and age were generated from relationships developed by other investigators at nearby sites (Supplemental Table 1). We do not know the extent to which site-specific factors such as soil texture, soil depth, nutrient availability, climate, and disturbance regimes may affect these relationships. Similarly, we estimated the size of cut trees based on allometric relationships developed in the live juniper stand. We assume that this relationship is robust to the closely co-located cut juniper stand, but unanticipated differences could exist between these two stands. Our space-for-time substitution did not include pre-treatment measurements, leaving open the possibility that starting conditions or post-treatment trajectories differed between the sites. Root and wood decay present particular challenges due to how infrequently these variables are measured. For both of these variables we used decay constants derived from global syntheses. Wood decay studies were primarily from temperate forests (Russell et al. 2015). Root decay studies included a wide range of climate zones (Silver and Miya 2001), although we assume that the bulk of studies were similarly from temperate mesic systems, given general trends for overrepresentations of these systems in ecological studies. Furthermore, for both root and wood decay, long-term decay may have different decay constants than the short-term measurements made for most studies and factors such as wood or root diameter, density, decomposer communities present, and soil texture may affect realized decay rates. Similar data availability is not the case for many study areas, calling for the importance of basic ecological data for estimating $\mathrm{C}$ pools (e.g., allometric, age, root distribution, and $\mathrm{C}$ concentration data). Finally, our analysis is limited by lack of uncertainty analysis for individual juniper and landscape-level $\mathrm{C}$ estimates. Lack of error information from some of our published data sources prevented us from propagating error through our $\mathrm{C}$ pool calculations.

Projecting into the future

By considering the size of both live and cut junipers, we were able to project patterns of changes in $\mathrm{C}$ pools through different landscape cover scenarios. Our projections suggest a high $\mathrm{C}$ storage potential with further encroachment, with increased juniper density leading to $\mathrm{C}$ increases primarily in juniper biomass (root and aboveground), surface SOC, and litter $\mathrm{C}$ pools. We assumed that increasing juniper density would lead to a decrease in sagebrush cover. Low $\mathrm{C}$ concentrations in shrub $\mathrm{C}$ pools led to little impact on $\mathrm{C}$ pools with shifting sagebrush cover. Sagebrush cover values at Walker Butte are quite low relative to other juniper-encroached sagebrush-steppe systems (3\% cover at Walker Butte, relative to mean of $12.1 \%$ at 9 other sites; Miller et al. 2014), suggesting that ecosystem $\mathrm{C}$ pools at other sites have the potential for greater sagebrush impacts that measured at Walker Butte. However, changes in juniper cover may have substantial impacts on other ecosystem services. In particular, juniper encroachment into historically sagebrush-dominated systems is of concern given the critical role that sagebrush plays in habitat for sage grouse (Miller et al. 2011).

Our projections regarding future land cover scenarios were based on simple increases in juniper cover through time and concomitant proportional declines in sagebrush cover. However, episodic mortality events may also influence patterns of juniper size and cover and consequent ecosystem $\mathrm{C}$ pools. Analysis of aerial photographs from eastern Oregon, USA, found that roughly one percent of the juniper in the study area was cut or burned annually, resulting in a roughly $35 \%$ decrease in aboveground $\mathrm{C}$ accumulation relative to unchecked woody encroachment (Campbell et al. 2012). In contrast, in southwestern Colorado, droughtinduced juniper dieback may be a bigger driver in $\mathrm{C}$ dynamics than management activities (Huang et al. 2010). 
Decreasing uncertainty in the role of wood encroachment and brush management in local to regional ecosystem $\mathrm{C}$ pools will require substantial increases in available data. Our analyses suggest predictable patterns of surface SOC and litter C relative to live and cut junipers, and that these patterns are dynamic through time with changing juniper size and management. Coupling this spatially-intensive surface $\mathrm{C}$ information with shrub distribution and allometric data appears to be an effective method for characterizing ecosystem $\mathrm{C}$ pools, offering an opportunity for filling in knowledge gaps regarding woody encroachment and brush management impacts on local-to-regional ecosystem $\mathrm{C}$ pools.

Acknowledgements This work was possible due to the existing SageSTEP Project at Walker Butte. We are grateful to the SageSTEP Project for allowing this work at the site. In particular, R.F. Miller, P. Doescher, and D. Pyke provided valuable discussion regarding site history and logistical support for site access. We appreciate field assistance from A. Derr and laboratory assistance from M. Bravo-Garza and Y. An. This is Contribution Number 127 of the Sagebrush Steppe Treatment Evaluation Project (SageSTEP), funded by the US Joint Fire Science Program (05-S-08) and the Bureau of Land Management. Financial support for field work and analyses was provided by United States National Science Foundation Grant DEB 0953864.

\section{References}

Archer S (1994) Woody plant encroachment into southwestern grasslands and savannas: rates, patterns and proximate causes. In: Vavra M, Laycock WA, Pieper RD (eds) Ecological implications of livestock herbivory in the West. Society for Range Management, Denver, pp 13-68

Archer S, Predick K (2014) An ecosystem services perspective on brush management: research priorities for competing land-use objectives. J Ecol 102:1394-1407

Archer S, Schimel DS, Holland EA (1995) Mechanisms of shrubland expansion: land use, climate, or $\mathrm{CO}_{2}$ ? Clim Change 29:91-99

Archer SR, Andersen EM, Predick KI, Schwinning S, Steidl RJ, Woods SR (2017) Woody plant encroachment: causes and consequences. In: Briske DD (ed) Rangeland systems: processes, management and challenges. Springer, Cham, pp 25-84

Barger NN, Archer SR, Campbell JL, Huang CH, Morton JA, Knapp AK (2011) Woody plant proliferation in North American drylands: a synthesis of impacts on ecosystem carbon balance. J Geophys Res Biogeosciences 116:G00K07

Barnes PW, Throop HL, Archer SR, Breshears DD, McCulley RL, Tobler MA (2015) Sunlight and soil-litter mixing: drivers of litter decomposition in drylands. Prog Bot 76:273-302

Baruch-Mordo S, Evans JS, Severson JP, Naugle DE, Maestas JD, Kiesecker JM, Falkowski MJ, Hagen CA, Reese KP (2013) Saving sage-grouse from the trees: a proactive solution to reducing a key threat to a candidate species. Biol Conserv 167:233-241

Bates D, Maechler M, Bolker B, Walker S (2015) lme4: linear mixed-effects models using Eigen and S4. R package version 1.1-9

Campbell JL, Kennedy RE, Cohen WB, Miller RF (2012) Assessing the carbon consequences of western juniper (Juniperus occidentalis) encroachment across Oregon, USA. Rangel Ecol Manag 65:223-231

Cotrufo MF, Wallenstein MD, Boot CM, Denef K, Paul E (2013) The Microbial Efficiency-Matrix Stabilization (MEMS) framework integrates plant litter decomposition with soil organic matter stabilization: do labile plant inputs form stable soil organic matter? Glob Change Biol 19:988-995

DeMarco J, Filley T, Throop HL (2016) Patterns of woody plant-derived soil carbon losses and persistence after brush management in a semi-arid grassland. Plant Soil 406:277-293

Eldridge DJ, Bowker MA, Maestre FT, Roger E, Reynolds JF, Whitford WG (2011) Impacts of shrub encroachment on ecosystem structure and functioning: towards a global synthesis. Ecol Lett 14:709-722

Fernandez DP, Neff JC, Huang CY, Asner GP, Barger NN (2013) Twentieth century carbon stock changes related to piñon-juniper expansion into a black sagebrush community. Carbon Balance Manag 8:1-13

Gholz HL (1980) Structure and productivity of Juniperus occidentalis in central Oregon. Am Midl Nat 103:251-261

Gibbens RP, Lenz JM (2001) Root systems of some Chihuahuan Desert plants. J Arid Environ 49:221-263

Harris D, Horwath WR, van Kessel C (2001) Acid fumigation of soils to remove carbonates prior to total organic carbon or carbon-13 isotopic analysis. Soil Sci Soc Am J 65:1853-1856

Houghton RA (2003) Revised estimates of the annual net flux of carbon to the atmosphere from changes in land use and land management 1850-2000. Tellus 55B:378-390

Huang CY, Asner GP, Barger NN, Neff JC, Floyd ML (2010) Regional aboveground live carbon losses due to droughtinduced tree dieback in pinyon-juniper ecosystems. Remote Sens Environ 114:1471-1479

Jackson R, Canadell J, Ehleringer J, Mooney H, Sala O, Schulze E (1996) A global analysis of root distributions for terrestrial biomes. Oecologia 108:389-411

Janisch JE, Harmon ME, Chen H, Fasth B, Sexton J (2005) Decomposition of coarse woody debris originating by clearcutting of an old-growth conifer forest. Ecoscience 12:151-160

King AW et al (2007) The first state of the carbon cycle report (SOCCR): the North American carbon budget and implications for the global carbon cycle. NOAA, National Climatic Data Center, Asheville

Klemmedson JO, Tiedemann AR (2000) Influence of western juniper development on distribution of soil and organic layer nutrients. Northwest Sci 74:1-11 
Knapp AK et al (2008) Shrub encroachment in North American grasslands: shifts in growth form dominance rapidly alters control of ecosystem carbon inputs. Glob Change Biol 14:615-623

Krämer S, Miller PM, Eddleman LE (1996) Root system morphology and development of seedling and juvenile $J u$ niperus occidentalis. For Ecol Manag 86:229-240

Lamlom S, Savidge RA (2003) A reassessment of carbon content in wood: variation within and between 41 North American species. Biomass Bioenergy 25:381-388

McClaran MP, Moore-Kucera J, Martens DA, van Haren J, Marsh SE (2008) Soil carbon and nitrogen in relation to shrub size and death in a semi-arid grassland. Geoderma 148:60-68

McIver J, Brunson M (2014) Multidisciplinary, multisite evaluation of alternative sagebrush steppe restoration treatments: the SageSTEP project. Rangel Ecol Manag 67:435-439

McIver J et al (2014) Synopsis of short-term response to alternative restoration treatments in sagebrush-steppe: the SageSTEP Project. Rangel Ecol Manag 67:584-598

McKinley D, Blair J (2008) Woody plant encroachment by Juniperus virginiana in a mesic native grassland promotes rapid carbon and nitrogen accrual. Ecosystems 11:454-468

Miller RF, Tausch RJ (2001) The role of fire in pinyon and juniper woodlands: a descriptive analysis. In: Paper presented at the fire conference 2000: the first national congress on fire ecology, prevention, and management, Tallahassee, FL

Miller RF, Bates JD, Svejcar TJ, Pierson FB, Eddleman LE (2005) Biology, ecology, and management of western juniper (Juniperus occidentalis). Technical Bulletin 152. Oregon State University Agricultural Experiment Station, Corvallis

Miller RF, Tausch RJ, McArthur E, Durant J, Dustin D, Sanderson SC (2008) Age structure and expansion of pinyonjuniper woodlands: a regional perspective in the intermountain west. Res. Pap. RMRS-RP-69. United States Department of Agriculture

Miller RF, Knick ST, Pyke DA, Meinke CW, Hanser SE, Wisdom MJ, Hild AL (2011) Characteristics of sagebrush habitat and limitations to long-term conservation. In: Knick ST, Connelly JW (eds) Greater Sage-Grouse: ecology and conservation of a landscape species and its habitat. Studies in avian biology, vol 38. University of California Press, Berkeley

Miller RF, Ratchford J, Roundy BA, Tausch RJ, Hulet A, Chambers J (2014) Response of conifer-encroached shrublands in the Great Basin to prescribed fire and mechanical treatments. Rangel Ecol Manag 67:468-481

Naito AT, Cairns DM (2011) Patterns and processes of global shrub expansion. Prog Phys Geogr 35:423-442

Nakagawa S, Schielzeth H (2012) A general and simple method for obtaining $\mathrm{R}^{2}$ from generalized linear mixed-effects models. Methods Ecol Evol 4:133-142

Neff JC, Barger NN, Baisden WT, Fernandez DP, Asner GP (2009) Soil carbon storage responses to expanding pinyonjuniper populations in southern Utah. Ecol Appl 19:1405-1416

Neilson RP, Lenihan JM, Bachelet D, Drapek RJ (2005) Climate change implications for sagebrush ecosystem. In:
Transactions of North American wildlife and natural resources conference, $\mathrm{p}$ 145-159

Norris MD, Blair JM, Johnson LC (2001) Land cover change in eastern Kansas: litter dynamics of closed-canopy eastern redcedar forests in tallgrass prairie. Can J Bot 79:214-222

Okin GS, Murray B, Schlesinger WH (2001) Degradation of sandy arid shrubland environments: observations, process modelling, and management implications. J Arid Environ 47:123-144

Pacala SW et al (2001) Consistent land- and atmosphere-based U.S. carbon sink estimates. Science 292:2316-2320

Rasse D, Rumpel C, Dignac M-F (2005) Is soil carbon mostly root carbon? Mechanisms for a specific stabilisation. Plant Soil 269:341-356

Rau BM et al (2011) Woodland expansion's influence on belowground carbon and nitrogen in the Great Basin U.S. J Arid Environ 75:827-835

Ross MR, Castle SC, Barger NN (2012) Effects of fuels reductions on plant communities and soils in a pinon-juniper woodland. J Arid Environ 79:84-92

Roundy BA et al (2014) Understory cover responses to piñonjuniper treatments across tree dominance gradients in the Great Basin. Rangel Ecol Manag 67:482-494

Rowland MM, Suring LH, Tausch RJ, Geer S, Wisdom MJ (2008) Characteristics of western juniper encroachment into sagebrush communities in central Oregon. United States Department of Agriculture, La Grande

Russell MB, Fraver S, Aakala T, Gove JH, Woodall CW, D'Amato AW, Ducey MJ (2015) Quantifying carbon stores and decomposition in dead wood: a review. For Ecol Manag 350:107-128

Silver WL, Miya RK (2001) Global patterns in root decomposition: comparisons of climate and litter quality effects. Oecologia 129:407-419

Sollins P, Kramer MG, Swanston C, Lajtha K, Filley T, Aufdenkampe AK, Wagai R, Bowden R (2009) Sequential density fractionation across soils of contrasting mineralogy: evidence for both microbialand mineral-controlled soil organic matter stabilization. Biogeochemistry 96:209-231

Spears JD, Holub SM, Harmon ME, Lajtha K (2003) The influence of decomposing logs on soil biology and nutrient cycling in an old-growth mixed coniferous forest in Oregon, U.S.A. Can J For Res 33:2193-2201

Strand AE, Pritchard SG, McCormack ML, Davis MA, Oren R (2008) Irreconcilable differences: fine-root life spans and soil carbon persistence. Science 319:456-458

Throop HL, Archer SR (2007) Interrelationships among shrub encroachment, land management, and litter decomposition in a semidesert grassland. Ecol Appl 17:1809-1823

Throop HL, Archer SR (2008) Shrub (Prosopis velutina) encroachment in a semidesert grassland: spatial-temporal changes in soil organic carbon and nitrogen pools. Glob Change Biol 14:2420-2431

Throop HL, Archer SR, Monger HC, Waltman S (2012) When bulk density methods matter: implications for estimating soil organic carbon pools in rocky soils. J Arid Environ 77:66-71

Throop HL, Lajtha K, Kramer M (2013) Density fractionation and ${ }^{13} \mathrm{C}$ reveal changes in soil carbon following woody 
encroachment in a desert ecosystem. Biogeochemistry 112:409-422

Throop HL, Abu Salem M, Whitford WG (2017) Fire enhances litter decomposition and reduces vegetation cover influences on decomposition in a dry woodland. Plant Ecol 218:799-811

Tiedemann AR, Klemmedson JO (2000) Biomass and nutrient distribution of system nutrient budget for western juniper in central Oregon. Northwest Sci 74:12-24

Van Auken OW (2000) Shrub invasions of North American semiarid grasslands. Annu Rev Ecol Syst 31:197-215
Vermeulen SJ, Campbell BM, Mangono JJ (2000) Shifting patterns of fuel and wood use by households in rural Zimbabwe. Energy Environ 11:233-254

Woodbury PB, Heath LS, Smith JE (2007) Effects of land use change on soil carbon cycling in the conterminous United States from 1900 to 2050. Glob Biogeochem Cycles 21:GB3006

Zhang X, Wang W (2015) The decomposition of fine and coarse roots: their global patterns and controlling factors. Sci Rep 5:9940

Zhou Y, Boutton TW, Wu XB (2017) Soil carbon response to woody plant encroachment: importance of spatial heterogeneity and deep soil storage. J Ecol 105:1738-1749 